\title{
Reshaping workplaces: workplace innovation as designed by scientists and practitioners
}

\section{Steven Dhondt and Geert Van Hootegem}

\begin{abstract}
Current thinking in several disciplines (organisational economics, sociology, psychology) about organisations is starting to converge. Organisations are no longer considered a black box, adapting to the economic environment as will-less objects. There is a role to play for managers to choose the right organisational model. There is still some confusion in the research field regarding which organisational model will be most suited for future societal demands. Workplace Innovation is positioned as a solution, not only stressing organisational performance, but also delivering better quality of work. This article proposes a research agenda to help this positioning.
\end{abstract}

Keywords: Workplace innovation, organisational innovation, quality of work, digitisation, managerial technology 


\section{Introduction}

When Frederick Winslow Taylor (1911) wrote his book on Principles of Scientific Management, his social and business environment was boiling with major changes, new ideas and new inspirations. Taylor published his first book when the third part of Karl Marx's Das Kapital was published, in 1894 (Marx 1894). Marx himself died a decade before this. Countries were trying to deal with the uprising of the working class. Einstein was busy developing his relativity theory in physics. His insights would change the view on reality itself. For technology, it was the age of invention. The book on scientific management showed how to organise production to improve the performance of companies and of workers. In fact, the book was a collection of minor improvements for companies. It was also meant to improve working conditions for the direct worker: why do it the hard way, if you can do it the easy way? Ergonomics was invented in those days, occupational safety and health started as an applied science. A seemingly limited book in content, but the eventual impact was a major change of our society. It was not really received with great sympathy in those days either. Taylor had angered his engineering colleagues to such a degree that they did not want his book to be published by their association. His book led to a major strike for which Taylor needed to defend himself in the American Congress. Still, Erik Brynjolfsson and Andrew McAfee (2014), in their book on 'the second machine age', categorise this Taylor book as clinching the major change in our human society. It is the new organisation that brought us the prosperity we now have and made it possible to harness the different technological possibilities of that time (electricity, mechanisation).

Our current time is also seeing major shifts. Computers and internet are now pervading every dimension of our reality. Everything is getting digitised, robotised and automated. However technology itself cannot guarantee the creation of new value. Rather, most see the second machine age as extremely threatening for our labour markets. It is then no wonder that we see a new Capital published to criticise our own current times. Thomas Piketty (2014) published his English edition of Capital, and in only a couple of months we see discussions on inequality all over the nations. For a long time we have known that $1 \%$ of Americans own too much, but only now this unequal distribution seems to be recognised as unacceptable (see for example for earlier criticism of inequality by Kalleberg et al. 2009). Our current investments for economic growth, international trade and technological change cannot anymore be seen as neutral activities, all oriented at improving the situation for all citizens. No, we now know that our financial economy has a way to favour this $1 \%$ of Americans citizens. We do not think citizens believe anymore that financial institutions such as Goldman Sachs or Blackrock are operating for the benefit of their shareholders or their clients. The financial crisis has led to a major redistribution of funds, not necessarily in the direction of the greater number of citizens (Appelbaum et al. 2013).

Brynjolfsson and McAfee (2014) see digitisation, polarisation and inequality as the major changing forces in our economy. They have installed some Born Again Christian-expectations into all of us: "There is a major change out-there. Be ready for this, because if you are not ready, you will find yourself at the wrong side of the income divide". And the major idea in their book is that we need a new organisational paradigm. Taylorism and Fordism have outlived their usefulness. Lean production is too much oriented at reducing costs. If the technical components of an I-Phone only count for $6 \%$ of the total value of the IPhone, why should we even care for all these lean techniques (De Backer 2011)? What can help grow value? The European Commission does not insist on cost-reductions for our companies, the mantra is rather 'innovation, innovation, innovation'. Only innovation can help grow the economy, and only a growing economy can generate sufficient employment. Also the European Commission is 
asking the scientific communities which organisational models are necessary to start-up new value generation.

\section{The elephant in the room}

As in the time of Taylor, are the organisational solutions we are seeking, not already out there? Are we looking for the so-called elephant in the room? Which elements of the elephant are then visible or are needed?

- We can see the greater need for organisational concepts that tackle inequality. That might be a first element.

- We also know that we should not have organisational concepts that are limited to specialised care systems in organisations such as Total Productive Management, Corporate Social Responsibility. An optimal system is not produced by developing optimised parts. No, we should have approaches that see the organisation in an integral fashion. "Integral" is not only from the organisation perspective, but also integrates the organisation and its environment (Dhondt et al. 2013). Discussions have shifted from corporate social responsibility to shared value creation (Porter et al. 2012). We understand that it is not about costs, but about value.

- We know that there has been a major shift over the last decades in investment strategies of companies: companies are now investing more and more into intangibles. There is a new equilibrium emerging between tangible and intangible investments (Jona-Lasinio et al. 2011; Corrado et al. 2012). Such equilibrium changes everything at the management level of companies. It is insufficient to only be an expert in a technical subject to run a company. The time of technical engineers as managers is over. Social engineers should take over.

So, are we at a point that we can give this elephant a name? Are we going to codify the core elements of the model into a handbook for organisational design? Are we already at the end of the development? Most importantly, is workplace innovation this new concept (Pot et al. 2012)? According to Dutch statistics, only $16 \%$ of Dutch companies would have adopted such a model in 2011 (Volberda et al. 2011). The concept of workplace innovation was coined in a recent note by Appelbaum, Hoffer Gittel and Leana (2011). They tried to convince the first Obama administration to start investing in organisational innovation. They wrote this note pointing out the evidence and the benefits of supporting such a change in policy towards workplace innovation. Sadly, to no avail. Our efforts in Europe were more successful (Dhondt et al. 2012). The European Commission now wants the learning network EUWIN to inspire all companies in Europe to adapt workplace innovation.

\section{Convergence in thinking}

If workplace innovation is this elephant, how real is this elephant? Are we promoting a mirage? And can we deliver the building blocks? What do managers need to do tomorrow? And for that instance, what do trade unions and workers need to do? What can we bring to the table to make it more credible that workplace innovation is indeed this elephant? Is it relevant to look at it? Are these arguments sufficiently convincing to overcome the obvious? 
The main argument for the credibility of workplace innovation is that workplace innovation seems to be the result of the convergence in thinking in three disciplines: organisational economics, organisational sociology, organisational psychology.

The starting point however is economics. Neo-classical economics has never believed that organisation is a subject that is worth studying. Companies adapt themselves to their environment, like pudding to the cup. Nicholai Foss and Peter Klein (2012) say that this perspective treats the organisation as Shmoo capital. Sticky stuff of course, but no forms are to be discerned. We can treat the organisation as a black box. If the environment changes, then the organisation changes accordingly. If you do not adapt, then you will disappear. But as organisational sociologists have long time known, badly managed companies can survive a very long time. So, it must be deemed an important change in economic thinking to acknowledge that there is such a thing as organisational choice. Bloom and Van Reenen (2010) talk about 'managerial technology' replacing the 'organisational design' perspective. In the latter perspective, organisations adapt to the environment. In the former, managers need to consider a bunch of organisational directions. Foss and Klein (2012) insist that there is such a thing as entrepreneurial choice. They also insist that organisational economics has a long tradition, but that it completely disappeared from the agenda's by the mid-1970s. The re-invention of the organisation is therefore a re-connection to basic insights on how the functioning of companies can be improved from within and that it is important for policy to help find right choices. Foss and Klein also insist that the most optimal model probably will be the model in which as many as possible decision makers play a role. So, employee voice should be a driving force for organisations.

For organisational sociologists, the main question is how to distinguish between organisational strategies. It is important to analyse intention, values, power and unintended consequences. Where the organisational economist is interested into optimal models, the organisational sociologist is interested in dominant choices.

An important organisational psychology input is the demand-control model developed by Robert Karasek (Karasek 1978; Karasek et al. 1990). This model is still the best connection between elements in the organisational design and individual person level impacts on health and learning. The demand-control model shows how organisational design can be an important preventive tool to improve health of employees. Coronary heart disease can be combatted by preventive strategies (Kivimaki et al. 2012).

\section{Relevance of workplace innovation}

We can now link choices about the individual worker health and performance, to the organisational context, and relate this organisational context to explicit choices that managers need to make. That means that managers cannot hide anymore. For that matter, policy makers cannot hide behind the managers.

Organisational economists now working for the OECD (2013) have identified that the organisation is an extremely interesting and a strategic asset for international competition. A first observation is that the organisational concept of a company cannot run away. Other intangibles, in which managers can invest, can easily leave. Human Capital can be bought. Patents can be taken over. Designs can be counterfeited. Organisational design is quite difficult to copy (Haskel et al. 2012). A second observation is that it takes nearly six years to fully depreciate the investments into a new organisational form (Awano et al. 2010). So, you really should think very hard about the choices you want to make. 
A last observation is that, at the country level, we can see very different amounts of investment into organisational capital. In figure 1, we show the distribution of knowledge based capital (KBC) as calculated by the OECD. Organisational capital is a major component of economic competencies.

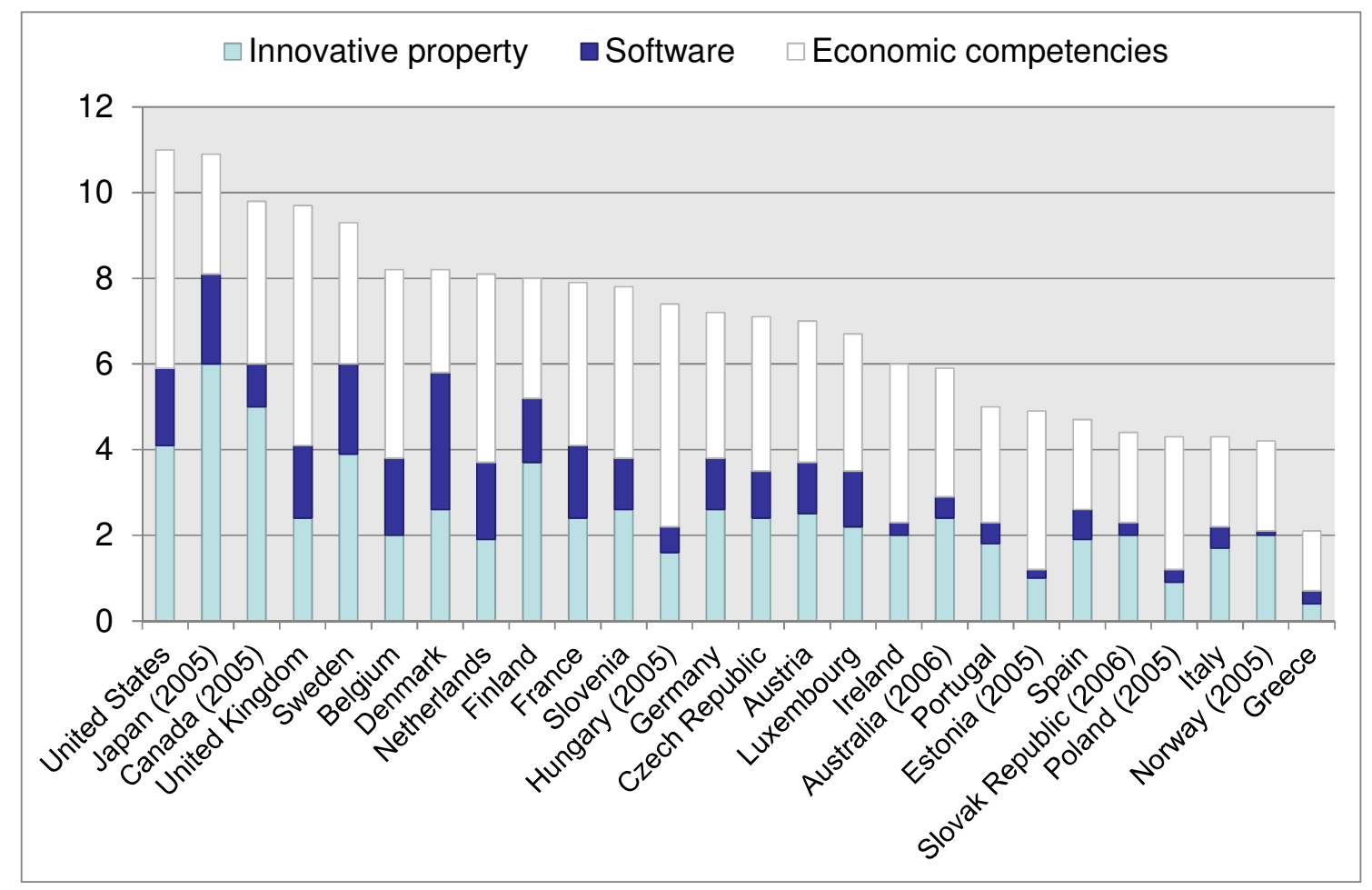

Tabell 1Investment in KBC varies significantly across countries. (Percent of GDP, selected OECD countries, 2009 or latest available data available) (OECD, 2013)

The distribution of countries according to workplace innovation is closely correlated to innovation results of countries. We calculated a .63 rank-order correlation between the ranking of countries in innovation performance (Hollanders and Es-Sacki 2013) and in ranking of workplace innovation scores (Dhondt et al. 2014).

\section{Too much organisational innovation, too little workplace innovation}

We are not yet sure that we are talking about workplace innovation in all of these results. Our measurements are far from precise. At the one side, we classify too many organisational phenomena under the heading of WPI. WPI is not the same as organisational capital. It is a subset, and the major research by the OECD or the Conference Board is not precise enough (OECD, 2013). The concept of organisational capital has only been developed and the measurements vary quite significantly over the studies. The core elements such as employee voice and work design (Black and Lynch, 2003) are not yet included in the measurements.

At the other side, some of our approaches such as dynamic capabilities (Teece et al. 1997) or HR-bundles (Sheehan 2014) measure too little (only management innovation). Bloom and Van Reenen (2010), for example, identify 18 management practices in their World Management Survey. In fact, they are only looking at control structures. This is not enough to find those companies that develop bottom-up procedures. It is quite complicated to identify workplace innovation-companies, only starting from the management view. 
So the main starting point should still be better measurement, using the right concepts. But it is also in the attitude towards organisational design. If we want to tackle the organisation, we need to become social engineers. Modern socio-technology is such a right social engineering approach (Van Hootegem et al. 2008). We cannot design organisations if we are thinking in terms of 'dominant practice'. We need to develop optimal social organisational practices with clear building principles.

\section{Directions for further development of workplace innovation ${ }^{1}$}

So, there is continuing progress in our field of work. We are starting to identify the contours of the organisational model that Brynjolfsson and McAfee (2014) want us to find. There is still a lot that needs to be done. Thinking and practice about workplace innovation needs to be developed in four directions.

The first discussion is on the theoretical underpinning of the workplace innovation by modern socio-technology. There are competing theoretical approaches such as Relational Co-ordination (Gittel et al. 2010a; 2010b) and design thinking (Boland and Collopy 2004). The combination of such approaches is needed to improve our understanding of organisational realities, and to translate this understanding in clear design principles.

A second discussion is on modern socio-technology and agency. As an approach focusing on designing organisation structures, modern socio-technology has been criticised for neglecting agency. A proper structure may enable proper behaviour, yet this does not come about automatically as taken for granted in sociotechnical design. For example, modern sociotechnology needs to integrate thinking about professional logics.

A third discussion is how to assess different organisational models and find out if they are 'optimal' for certain contexts. The question is to what degree redesigned organisations are performing better than networks of self-employed or lean production, how networks of organisations function.

A last discussion is on how to relate the modern socio-technical model to innovation performance. The current modern sociotechnical theories do not conceptualise explorative and exploitative functions in the innovation activities of organisations (Lekkerkerk 2012).

\section{In conclusion}

Our current societal context requires a new integration of theoretical and practical knowledge on the organisation. Brynjolfsson and McAfee (2014) predict that only if we succeed in developing this integration, then we will see a new productivity jump and better use of the 'machines' as they are now among us. We rather need a race with the machines, than against them (Brynjolfsson and McAfee 2014). Even if we succeed in this, we must remain modest. This integration to reshape workplaces will cost time and effort. And bringing this result may also not give us or you the rewards you expect. Taylor died from pneumonia only 4 years after publishing "Scientific Management". The long term results of developing this workplace innovation are great: less inequality, better quality of work, more productive companies, and most of all, more innovative companies.

\footnotetext{
${ }^{1}$ During the EGOS-Conference of 2014 (Rotterdam), there was a special Sub-Stream (53) on workplace innovation. We thank the different participants in this session for their input and discussion.
} 


\section{References}

Appelbaum E., Hoffer Gittell J., Leana C. (2011). High-Performance Work Practices and Sustainable Economic Growth, Washington: CEPR - Center for Economic and Policy Research, March 20.

Appelbaum E., Batt R., Clark I. (2013). Implications of Financial Capitalism for Employment Relations Research: Evidence from Breach of Trust and Implicit Contracts in Private Equity Buyouts. British Journal of Industrial Relations, 51:3 September, 498-518

Awano G., Franklin M., Haskel J., Kastrinaki Z. et al. (2010). Measuring investment in intangible assets in the UK: Results from a new survey, Economic and Labour Market Review, Vol: 4, Pages: 66-71

Black S.E., Lynch L.M. (2003). What's driving the New Economy?: The Benefits of Workplace Innovation. FRBSF Working Paper 2003-23, 38 pages.

Bloom N., Van Reenen J. (2010). Why do management practices differ across firms and countries? Journal of Economic Perspectives, Vol. 24, Nr.1, winter, 203-224

Boland R., Collopy F. (eds) (2014). Managing as designing. Stanford (SA): Stanford University Press.

Brynjolfsson E., McAfee A. (2014). The second machine age. Work, progress, and prosperity in a time of brilliant technologies. New York: W.W. Norton.

Corrado C., Hulten C., Sichel D. (2005). Measuring Capital and Technology: An Expanded Framework. In: Corrado C., Haltiwanger J., Sichel D. Measuring Capital in the New Economy. National Bureau of Economic Research Studies in Income and Wealth, Vol. 65, Chicago: University of Chicago Press, 11-45.

Corrado C., Haskel J., Jona-Lasinio C., Iommi M., et al. (2012). Intangible capital and growth in advanced economies: measurement methods and comparative results, Intangible capital and growth in advanced economies: measurement methods and comparative results, London: Imperial College Business School

De Backer K. (2011). Global Value Chains: Preliminary evidence and policy issues (agenda point 4). Paris: OECD. (WPGI-meeting).

Dhondt S., Broekman C., Torre W., van der Berg C. and van de Wiezer N. (2013). Co-creatie van organisaties met consumenten als een hefboom voor sociale innovatie. Bouwstenen voor duurzame co-creatie. $M \& O$ (September/Oktober), Nr.5, 107-124.

Dhondt S., Oeij P., Totterdill P., Howaldt J., Van Hootegem G., Van Gramberen M. (2012). The DortmundBrussels Position Paper on Workplace Innovation. Dortmund/Brussels: TNO, sfs-Dortmund.

Dhondt S., Preenen P., Oeij P., Corral A., Isusi I., Totterdill P., Karanika-Murray M. (2014). European Company Survey: construction of the workplace innovation index and selection of companies. Hoofddorp: TNO.

Foss N., Klein P.G. (2012). Entrepreneurial Judgment and the Theory of the Firm. Cambridge: Cambridge University Press.

Gittell J.H., Bamber G. (2010a). High and Low Road Strategies for Competing on Costs and Their Implications for Employment Relations: Studies in the Airline Industry. International Journal of Human Resource Management, 21(2), 165-179.

Gittell J.H., Seidner R., Wimbush J. (2010a). A Relational Model of How High-Performance Work Systems Work. Organization Science, 21(2), 490-506.

Hollanders H., Es-Sacki L. (2013). Innovation Union Scoreboard 2013. Brussels: European Commission (DG Enterprise \& Industry).

Hootegem G., Van Amelsvoort, P., Van Beek G., Huys R. (2008). Anders organiseren \& beter werken. Handboek sociale innovatie en verandermanagement. Leuven/Voorburg: Acco.

Jona-Lasinio C., Iommi M., Manzocchi S. (2011). Intangible capital and Productivity Growth in European Countries. Innodrive Working Papers Series No.10, Roma: LUISS-LLEE.

Kalleberg A.L., Nesheim T., Olsen K.M. (2009). Is Participation Good or Bad for Workers? Effects of Autonomy, Consultation and Teamwork on Stress Among Workers in Norway. Acta Sociologica, 52, 99-116. 
Karasek R.A. (1979). Job demands, job decision latitude, and mental strain: implications for job redesign. Administrative Science Quarterly, 24, 285-308.

Karasek R. A., Theorell T. (1990). Healthy Work. Stress, productivity and the reconstruction of working life. New York: Basic Books Inc.

Kivimäki M., Nyberg S.T., David Batty G., Fransson E.I., Heikkilä K., Alfredsson L., Bjorner J.B., Borritz M., Burr H., Casini A., Clays E., De Bacquer D., Dragano N., Ferrie J.E., Geuskens G. A., Goldberg M., Hamer M., Hooftman W.E., Houtman I.L., Joensuu M., Jokela M., Kittel F. (2012). Job strain as a risk factor for coronary heart disease: a collaborative meta-analysis of individual participant data. The Lancet, Volume 380, Issue 9852 , 27 October-2 November, Pages 1491-1497

Lekkerkerk L.J. (2012). Innovatie- en Organisatiestructuur. Ontwikkeling en test van een functiemodel voor structuuronderzoek en diagnose. Nijmegen: Radboud Universiteit/Innovatica.

Marx K. (1894). Capital. Volume III. The Process of Capitalist Production as a Whole. N.Y.: International Publishers.

OECD (2013). Knowledge Capital, Growth and Innovation. Paris: OECD.

Porter M., Kramer M. (2011). Creating Shared Value. Harvard Business Review; Jan/Feb, Vol. 89 Issue 1/2, p62$77,16 \mathrm{p}$

Pot F., Dhondt S., Korte E. de, Oeij P., Vaas F. (2012). Chapter 8: Workplace innovation in the Netherlands. In: Houtman I.L.D. (e.a.). (2012). Work Life in the Netherlands, Hoofddorp: TNO, 173-190.

Sheehan M. (2014) Human resource management and performance: Evidence from small and medium-sized firms. International Small Business Journal, Vol. 32 (5) 545-570

Taylor F.W. (1911). The Principles of Scientific Management. New York and London: Harper \& brothers

Teece D. J., Pisano G., Shuen A. (1997). Dynamic capabilities and strategic management, Strategic Management Journal, Vol. 18, No. 7, pp. 509-533

Volberda H., Jansen J., Tempelaar M., Heij K. (2011). Monitoren van sociale innovatie: slimmer werken, dynamisch managen en flexibel organiseren. Tijdschrift voor HRM, 1, 85-110.

\section{About the authors}

Steven Dhondt

Professor of Social Innovation, Catholic University of Leuven (Belgium), network coordinator of the European Workplace Innovation Network (EUWIN); senior research scientist at TNO,

Netherlands.

E-mail: steven.dhondt@tno.nl

\section{Geert van Hootegem}

Professor of Sociology of Work and Organization at the Centre for Sociological Research of Catholic University of Leuven,

Belgium.

E-mail: geert.vanhootegem@soc.kuleuven.be 